de Alwis, who u as merely employed to make accurate copies of his brother's drawings, need not be brought forward; Mr. Moore was perfectly aware who made the original drawings from nature. It is satisfactory to know that the preface will contain an acknowledgment of the real artist, but common honesty requires his name to be printed on every plate that he drew instead of "C. F. Moore."

k. Bot. Gardens, Peradeniya, Ceylon, January 9

\section{The Collection of Meteoric Dust-A Suggestion}

IN the Report of the Committee on Meteoric Dust, given in your report of the last meeting of the British Association (NATURE, vol. xxiv. p. 462), Prof. Schuster refers to the difficulty "found in the determination of the locality in which the observations should be conducted," as there are but few accessible places sufficiently sheltered " against any ordinary dust not of meteoric origin. The lonely spots best suited for these observations are generally accessible to occasional experiments only, and do not lend themselves easily to a regular series of observations." As it is highly important that such a regular series should be obtained, and that such observations should be made in places "sheltered as much as possible" from dust of terrestrial origin, I venture to think that these conditions would be complied with by employing suitably constructed captive balloons, carrying the collecting apparatus at the highest attainable altitude. By this means we should have the great advantage of not only making the experiments abroad, but the observations might also be made from some hill-top in the north of Scotland, sufficiently far from any manufacturing town to insure the necessary freedom from dust of terrestrial origin.

79, Marlborough Road, Dalston, E.

\section{Colour and Sound}

SOME weeks ago there appeared an account of a series of experiments connecting colour and sound; the following passage from Prof. Max Müller's Chips, ii. 104, may interest some of your readers :- "That Purûravas is an appropriate name of a solar hero requires bardly any procf. Pururavas meant the same as $\pi 0 \lambda v \delta \in v \kappa \eta ́$ s, endoned with much light; for though rava is generally used of sound, yet the root ru, which means originally to cry, is also applied to colour, in the sense of a loud or crying colour, i.e. red (cf. ruber, rufus, Lith, rauda, O.H.G. rôt, rudhira, épvepós ; also Sanskrit ravi, sun)." The following footnote occurs :- "Thus it is said, Rv. vi. 3,6 , the fire cries with light, sokisbâ rârapîti ; the two Spartan Charites are called $\mathrm{K} \lambda \eta \tau \dot{\alpha}$ ( $\kappa \lambda \eta \tau \alpha^{\prime}$, incluta) and $\Phi \alpha \epsilon \nu \nu a ́$, i.e. Clara, clear-shining. In the Veda the rising sun is said to cry like a new child (Rv. ix. 74, I ) - I do not derive ravas from rap, but I only quote rap as jllustrating the close connection between loudness of sound and brightness of light."

Both Greeks and Latins seem to have used the same words

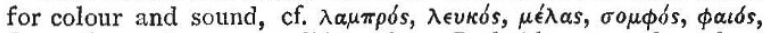
$\& c$. ; clarus, fuscus, candidus, \&c. Probably not only colour and sound, but smell, taste, and touch had in early times the like words to express degree; even as we find aspera lingua and odor asper; and as we say "a harsh taste" and "a harsh sound." T astes and smells will be found to suggest colours to the mind exactly as sounds do. If this be so, may not this apparently curious connection be explained as a sort of "unconscious philological memory?"

Inner Temple, January 28

\section{On the Climate of North Northumberland as Regards} its Fitness for Astronomical Observations

A LeTter in the last issue of NATURE (p. 3I 7) upon the above subject, not altogether agreeing with the published records of this station, I should like to ask the reverend gentleman whether his observations were taken promiscuously; at stated times, or extending from sunset to sunrise. As the summary does not "tally" with the "weather at time" or "weather since taken" without a break durin' $\mathrm{I} 88 \mathrm{r}$ at 6 p.m. and 9 a.m. daily, I am afraid that a misconception will be formed as to the weather here by the readers of NATURE, and as this station is about 300 yards from Mr. Perry's observatory, there must te a mistake upon one side or the other, or probably the astronomical and meteorological definitions of "completely overcast" are different.

JOSEPH IINGWOOD

Meteorological Society's Station, Alnwick, February 4

\section{Farhelia in the Mediterranean}

ON the morning of the $27^{\text {th }}$ inst. a curious sight was witnessed at tbis place. I was sailing on the Mediterranean, and the day was hot and sunny. A slight haze came on, and about noon a large halo with an orange tint surrounded the sun. Shortly afterwards two mock suns appeared, one on each side of the ring round the central sun. They were also tinged with an orange colour, and appeared to have comet-like tails. $\mathrm{Re}$ flected in the still blue water they were even more distinct than when looked at direct, as the water cut off the sun's rays. This singular spectacle lasted more than an kour, and was seen by many. The boatmen predicted bad weather, but it has not yet come. All through January we have had brilliant summer days, with cold starlight nights- the minimum thermometer descending to $38^{\circ}$ and $36^{\circ}$ almost every night. I send you a very rough sketch of the mock suns.

Mentone, Alpes Maritimes, January

Chas. H. Allen

\section{SIR ROBERT CHRISTISON}

$\mathrm{N}$ OTWITHSTANDING his advanced age, the announcement of the death of Sir Robert Christison will be received with universal regret. $\mathrm{He}$ died on January 27, from the effects of a cold caught a month previously. Sir Robert's father was for many years Professor of Humanity in the University of Edinburgh, where the son was born on July I 8, 1797. He attended first the High School, and subsequently the Arts Classes at the University. Having been well grounded in literature and general science, he turned his attention to medical studies, and graduated as Doctor of Medicine in 1819 . Proceeding to the schools of London and Paris, in the latter city he became a pupil of Robiquet, the eminent chemist and pharmacien, in whose laboratory he worked assiduously, and, as he used often to say in after life, with signal advantage. Here, too, he is understood to have prosecuted, under the celebrated Orfila, that study of toxicology to which he had all along shown a special bent, and in which he was destined to achieve so important results. Shortly after his return to Edinburgh the young physician was, in 1822; appointed to the University Chair of Medical Jurisprudence, in succession to Dr. Alison. This post he occupied till 1832 , when he relinquished it to assume the Chair of Materia Medica, rendered vacant by the death of Dr. A. Duncan, and for the clinical duties of which he was well qualified by hospital practice; while for its general work he had been thoroughly equipped by those old studies under Robiquet, followed up, in the interval, by diligent examination of every fresh pharmaceutical discovery.

Dr. Christison was able to give to the science of Medical Jurisprudence a precision it had formerly lacked, and thus contributed in no small degree to its practical development. Very important in this connection was the publication, in 1829 , of his "Treatise on Poisons," which was received at the time by physicians, jurists, and men of science generally, as the most philosophical exposition of the subject that had ever appeared, and is even now regarded as a work of great value. From his position as Professor of Medical Jurisprudence, Dr. Christison was naturally called upon to act as an expert in criminal trials ; and it was not long before his appearances in that capacity secured for him the reputation of a highly important witness.

In exchanging the Chair of Medical Jurisprudence for that of Materia Medica, Dr. Christison was, so to speak, confimed in that line of chemical research for which he had all along shown special predilection. In the laboratory he was noted as a peculiarly neat and clean worker - a qualification of the utmost importance in prosecuting, for example, delicate toxological experiments. Nor was his exactitude greater than the earnestness and enthusiasm with which he followed out any inquiry to its ultimate issues. The well-known case of the Calabar bean, 
in which an experiment on his own person was only prevented from proving fatal by timely swallowing of his shaving water, was a significant indication of the thoroughgoing spirit in which all his researches were pursued. As a pharmacien he rendered valuable service to the profession in connection with the last edition of the "Edinburgh Pharmacopœia," merged since 1864, like those of London and Dublin, in the "Pharmacopoeia Britannica," prepared under the auspices of the General Medical Council ; and in his "Dispensatory," published in 1842 (second edition, 1848 ), he presented a commentary on the then existing Pharmacopoias, characterised, like his book on Poisons, by precision in details, and by the concise, yet happy expression of suggestive gereralisations.

In the professorial chair Dr. Christison proved a singularly lucid and instructive lecturer. Himself strictly methodical in everything pertaining to scientific inquiry or professional routine, he fostered in his students habits of exact and well-regulated work. As the result of his incumbency, both the chairs he occupied gained no inconsiderable accession of usefulness and importance while to that of Materia Medica he left a substantial legacy in the splendid museum, whose riches can never be appreciated till it is properly displayed in the new Medical School. By his students he was loved as well as admired; and once and again, in the course of his long career, old pupils scattered far and wide as busy practitioners, have shown themselves prompt to embrace every opportunity of doing him honour.

As a member of the Senatus Academicus, and Assessor for that body in the University Court-an office to which he was elected five times in succession-Prof. Christison took an active and prominent part in the management of college affairs. No member of the University was more energetic in pushing forward that great scheme of extension which, as now all but realised in a new Medical School, alongside of the new Infirmary, will doubtless raise Edinburgh to a yet higher position as a seat of medical education. The movement for better endowment of the University also found a warm supporter in one who was ever ready to advance what he believed to be the true interests of learning. An ardent lover of all manly exercises, the doctor was himself noted, in his youth, as the most accomplished athlete in the University. A story is told of his having, on one occasion, accomplished the rarely equalled feat of running from the College gate to the top of Arthur seat within twenty-five minutes. In after years, athleticism would often form part of the diversions with which the Professor and his friends relieved the cares of professional life. Even as an octogenarian the vivacious Professor continued to be remarked for the almost jaunty elasticity of his step.

By the Edinburgh Medical Faculty his eminence was duly recognised in his election on two distinct occasions - in 1838 , and again in 1846 --to the presidentship of the Royal College of Physicians, an honour which was fitly followed up by the Fellows according a place in their hall to his portrait by Sir John Watson Gordon. On the death of Sir David Brewster, he was elected president of the Edinburgh Royal Society; and in this office, held from 1868 to 1873 , as well as in the vice-presidentship, which he had formerly filled, he acquitted himself with a distinction which the Society acknowledged by adding his portrait to their gallery of illustrious men. Assiduous in his attendance at the Society's meetings, Dr. Christison from time to time contributed papers to the Transactions. Among the subjects thus discussed may be mentioned that of fossil plants in the coal formation, and the remains of ancient trees found in Craigleith and other quarries, on the study of which he brought to bear the resources of chemical analysis. In 1857 Dr. Christison's position among Scotch physicians was fitly recognised in his being nominated by the Crown to represent the profession in Scotland at the General Medical Council. After having for many years held the honorary office of a Physician in Ordinary to the Queen for Scotland, Prof. Christison in I 87 I was created a baronet of the United Kingdom, a distinction which was conferred on the recommendation of the then Prime Minister, Mr. Gladstone. In I873 he celebrated the jubilee of his professorship, an occasion of which friends and admirers were eager to take advantage for testifying their appreciation of the veteran physician. In 1875 he presided over the Edinburgh meeting of the British Medical Association. The veteran's general standing as a scientific man was no less unmistakably certified in his being selected, in 1876 , for the presidentship of the British Association for the Advancement of Science: though this honour, in deference to the advice of friends, who feared the effort might overtax his strength, he felt constrained to decline. It was not many months later that an illness, by which he was for a time completely prostrated, led to his resignation of professorial duty.

Sir Robert Christison was married in 1827 to Henrietta Sophia, daughter of Mr. David Brown, of Greenknowe, Stirlingshire. Mrs. Christison died in 1849 ; but there survive three sons, of whom Alexander, the eldest, born in 1828 , was educated at the Edinburgh Academy and High School, and after serving in various capacities, is now Deputy Surgeon-General of the Bengal Army.

\section{CONCERNING THE GAS-FLAME, ELECTRIC, AND SOLAR SPECTRA, AND THETK EFFECTS ON THE EYE}

THE spectra of the light from these various sources is a subject to which I gave some attention about two years ago, and a detailed account of my experiments may be found in the Proceedings. of the American Academy of Sciences for 1880 , p. 236 . In this article it was shown that the colour of the sun was not what the-average person would call white, but decidedly bluish. The sun's "golden glare" spoken of by Mr. Capron is entirely a subjective effect (except when near the horizon); and foliows from the well-known law that bright lights tend to look yellow, and faint on es blue. If the highly magnified images of two diaphragms equally illuminated, one by the electric light and one by the sun, be cast upon a screen, the distinctly bluish character of the latter will be strongly marked. Indeed, the magnesium light is more blue than the electric, and hence probably is of a higher temperature, although being spread through a larger space, has less available heating power. As far as mere colour is concerned then, the electric light approaches nearer to the sun than does the gas-flame.

From subsequent experiments, however, it is my impression that colour has nothing whatever to do with the painful effects sometimes noticed in the eyes, after long and continuous work by artificial light. To test this question, I had a tin lamp-shade constructed, consisting of a tube six inches in diameter by eight in length. One end was closed by a reflector, and the other by a piece of very light blue glass. Two holes were made in the sides, through which passed the glass chimney of an Argand gas-burner. By experimenting with a shadow photometer, a position was found where the light received on a book was of the same intensity, and very similar colour, to that from a window in the daytime, at a distance of about six feet. A few minutes' reading, however, was sufficient to convince me that the new light was far more trying to the eyes than an ordinary gas-flame would be. The illeffects being due to the intense heat thrown down by the reflector. And this I think is the source of the whole trouble in the ordinary gas-burner. The heat radiated by the flame, the heated chimney and shade, and reflected 